\title{
Estimating Frisch Labor Supply Elasticity in Japan
}

\author{
Sachiko Kuroda* and Isamu Yamamoto**
}

\begin{abstract}
Using Japanese data from the 1990s aggregated by prefecture, age group, and sex, we estimate Frisch labor supply elasticity, which has been seldom estimated in Japan. The change in labor supply can be decomposed into two labor-supply behaviors: extensive margin, indicating workers' entry and exit from the labor market; and intensive margin, indicating changes in hours of work in response to a wage change. Our estimates of the Frisch elasticity on the extensive and intensive margins combined are in the range of 0.2 to 0.7 for males, 1.3 to 1.5 for females, and 0.7 to 1.0 for both sexes. Our estimates of the Frisch elasticity on only the intensive margin are in the range of 0.1 to 0.2 for all three categories. These results suggest that extensive margin explains the bulk of labor-supply changes in Japan. As for the changes in the estimates of the Frisch elasticity in Japan from the 1990s, it has been either unchanged or in a declining trend on the extensive and intensive margins combined, either unchanged or in a slight rising trend on only the intensive margin, and in a declining trend on only the extensive margin.
\end{abstract}

Key words: Labor supply, Frisch elasticity, Extensive margin, Intensive margin

JEL classification: E24, J22

* Associate Professor, Hitotsubashi University (E-mail: kuroda@ier.hit-u.ac.jp)

** Associate Professor, Keio University (E-mail: yamamoto@fbc.keio.ac.jp)

This paper is partly based on our paper in Japanese "Hitobitowa Chinginno Henkanioujite Roudoukyoukyuwo Donoteido Kaeruka?: Roudoukyoukyudanseichino Gainenseirito Wagakunino Detawo Mochiita Suikei,” Kinyukenkyu, 26(2), Institute for Monetary and Economic Studies, Bank of Japan, 2007. We would like to thank for their valuable comments Fumio Ohtake (Osaka University), participants in the Conference on Changes in Japan's Economy since 1990 jointly sponsored by the Center for Advanced Research in Finance at Tokyo University and Research and Statistics Department, Bank of Japan, participants in the seminars at Kansai Institute for Social and Economic Research, and the staff at the Institute for Monetary and Economic Studies, Bank of Japan. We also thank Chie Arai (Bank of Japan), Takemasa Oda (Bank of Japan), and Rie Yamaoka (Bank of Japan) for their help in preparing the datasets. Views expressed in this paper are those of the authors, and do not necessarily reflect the official views of the Bank of Japan. Whatever errors that may be contained herein are solely those of the authors. 


\section{Contents}

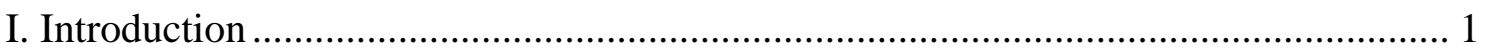

II. Estimation Models and Several Remarks …............................................................. 5

A. Estimation Model of Frisch Elasticity ................................................................... 5

B. Several Remarks When Estimating Labor Supply Elasticity ................................... 7

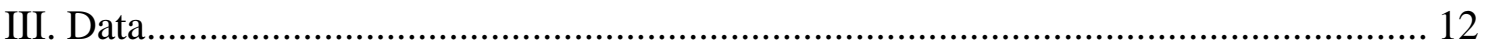

A. Hours of Work: Definitions in Datasets A and B ................................................ 13

B. Other Variables (Wages, Prices, Consumption, and Net Spending)........................ 14

IV. Estimation Results for Labor Supply Elasticity ...................................................... 15

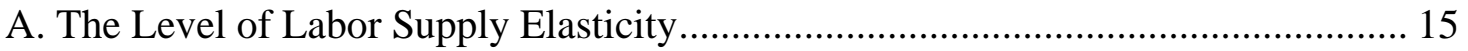

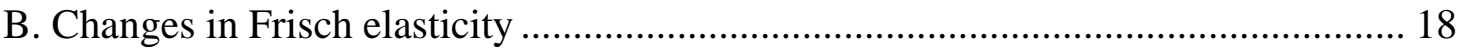

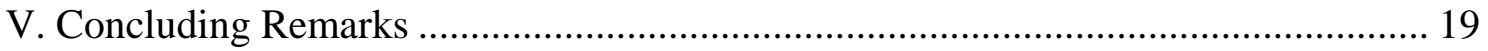

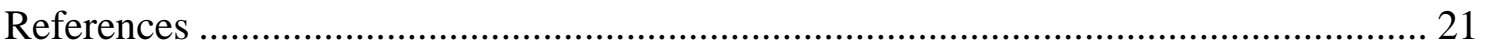




\section{Introduction}

Using Japanese data from the 1990s aggregated by prefecture, age group, and sex, we estimate Frisch labor supply elasticity (hereafter, Frisch elasticity) in Japan. As pointed out by Prescott (1986), Frisch elasticity is one of the most important structural parameters in economics. In the dynamic general equilibrium models used in macroeconomics, for example, the responses of endogenous variables to shocks largely depend on Frisch elasticity. To our knowledge, however, previous studies have not done much to estimate the elasticity in Japan. Given this situation, the main objective of this paper is to show parameter values of Frisch elasticity in Japan.

Frisch elasticity is a type of intertemporal labor supply elasticity, which is derived from standard dynamic models that solve the intertemporal utility maximization problem of a representative agent. We estimate Frisch elasticity based on a life-cycle model, a line of analysis that stems from the permanent income hypothesis from Friedman (1957, 1976). According to the life-cycle model, a representative agent changes his/her labor supply over the business cycle in response to the temporal wage changes induced by shocks (that is, to the deviation of actual wages from the permanent or expected wage). Frisch elasticity indicates the extent to which people change their labor supply in response to these temporary wage changes. There is a wealth of literature estimating Frisch elasticity using either aggregate or longitudinal data in the United States and European countries. Examples of such research include Lucas and Rapping (1969), Altonji (1982), Mankiw, Rotemberg, and Summers (1985), and Algoskoufis (1987), which use aggregate data, and MaCurdy (1981), Heckman and MaCurdy (1982), Browning, Deaton and Irish (1985), and Altonji (1986), which use longitudinal data.

As for Japan, however, there is a paucity of empirical research on Frisch Elasticity. Consequently, the parameter value derived from US or European research is typically used without modification when conducting simulations on dynamic general equilibrium models in Japan. Should there be substantial differences in labor market characteristics across countries, however, this may be reflected in different labor supply behavior in Japan. In this regard, it is worth estimating the elasticity for Japan using its own data. In addition, because of this lack of estimates for Frisch elasticity, we do 
not yet know whether there is an inconsistency between theory and empirical evidence ${ }^{1}$ in Japan as has been the case in the US and European literature. That is, when the parameter values of Frisch elasticity obtained in empirical analyses have been plugged into simulations of theoretical models, those simulations have usually done a poor job in describing the real economy.

As stated above, there is no prior research specifically aimed at estimating Frisch elasticity in Japan. The only related research would be Osano and Inoue (1991), which uses Japanese time series data to estimate Euler equations for consumption and leisure. Although their main purpose is to examine the validity of life-cycle models and implicit contract theory, we can infer the Frisch elasticity from their estimation results - about 0.06 to 0.13 .

Our approach differs from that of Osano and Inoue (1991) in several respects. First, our primary objective is to provide the estimates for Frisch elasticity. To achieve this objective, we also estimate m-supply, Marshallian, and Hicksian labor supply elasticities. We do this because these other elasticities are robust to liquidity constraints, and at the same time they provide additional information regarding the size of Frisch elasticity. Since there is a theoretical relationship in size between Frisch and other elasticities, we can specify the upper and lower bound of the Frisch elasticity. Second, we estimate Frisch elasticity using not only time series variation but also cross-sectional variation with data on hours of work, wages, and other variables aggregated by prefecture, age group, and sex. Third, using aggregate data enables us to estimate labor-supply behavior on the extensive margin and intensive margins combined, while Osano and Inoue (1991) estimate Frisch elasticity only on intensive margin. $^{2}$ By extensive margin, we mean the marginal change in the number of people who enter into/exit from the labor market in response to temporary marginal wage

\footnotetext{
${ }^{1}$ Much of the empirical research using longitudinal data thus far estimates a small Frisch elasticity near zero, but normally a parameter value for Frisch elasticity of around 1 or larger is used when simulating dynamic general equilibrium models (for example, Rotemberg and Woodford [1998] use an elasticity close to 9). Within the real business cycle literature, a number of papers use the concept of indivisible labor to derive an infinite Frisch elasticity (for example, King and Rebelo [1999] use an elasticity of 4 in their basic model, and an infinite elasticity in an extension of their model). For a description of indivisible labor, see Hansen (1985), Rogerson (1988), and Browning, Hansen, and Heckman (1999).

${ }^{2}$ Osano and Inoue (1991) use the total hours of work by full-time manufacturing workers (Monthly Labor Survey; the Ministry of Health, Labor and Welfare), and estimate Frisch elasticity along the intensive margin.
} 
changes. By intensive margin, we mean the marginal changes in hours of work for those already employed in response to temporary marginal wage changes. In the review of empirical studies for the United States, Heckman (1993) concludes that most of the change in the labor supply reflects changes in the number of people entering and exiting the labor market. That is, extensive margin explains most of the fluctuation in the labor supply. If this also applies to Japan, the parameter value for Frisch elasticity in macro models shall include not only intensive but also extensive margin to describe a representative agent's labor supply behavior. As is done in Lucas and Rapping (1969), using aggregate data enables us to estimate Frisch elasticity in both extensive and intensive combined ${ }^{3}$. Lastly, to examine the possibility that Japan's labor market underwent structural change during the so-called "lost decade" of the 1990s, we also examine whether or not Frisch elasticity changed during the 1990s. ${ }^{4}$

The results of this paper can be summarized as follows. First, Frisch elasticity on the extensive and intensive margins combined is in the range of 0.7 to 1.0 when we pool data on males and females together (in our paper, we call this "both sexes”). We conclude that our estimates of Frisch elasticity are not very different from those suggested in the US empirical studies, such as Lucas and Rapping (1969), Algoskoufis (1987) and Mulligan (1999). ${ }^{5} \quad$ Second, we find large differences in Frisch elasticity by sex, with males having elasticity in the range of 0.2 to 0.7 , and females in the range of 1.3 to 1.5. Third, Frisch elasticity on the intensive margin only is very low for both sexes, males, and females, in the range of 0.1 to 0.2 . The last finding is consistent with Heckman (1993), that extensive margin dominates intensive margin in most of the changes in labor supply behavior.

\footnotetext{
${ }^{3}$ Mulligan (1999) also estimates Frisch elasticity in extensive and intensive combined, by taking cell-mean of individual data in Current Population Survey. His results are relatively similar with those obtained in previous studies using aggregate data such as Lucas and Rapping (1969) or Algoskoufis (1987).

${ }^{4}$ The rapid increase in part-time workers has been cited as evidence of the possibility that Japan's labor market underwent structural change in the 1990s. For example, Sakura, Sasaki, and Higo (2005) point out the possibility that labor elasticity may have increased as a result of the changes in preferences over the choice between labor and leisure of females and younger people, which is reflected in the rapid increase in part-time workers in the 1990s.

${ }^{5}$ This implies that there is also an inconsistency between theory and empirical evidence in Japan. For example, Hayashi and Prescott (2001), in their RBC model, use an infinite elasticity to describe Japan's lost decade in the 1990s.
} 
Regarding possible changes in Frisch elasticity in the 1990s, it has been either unchanged or slightly declining on the extensive and intensive margins combined. When we decompose it into the two margins, however, intensive margin was either unchanged or slightly rising whereas the extensive margin was possibly declining.

This paper is organized as follows. In section II, we derive our estimation models and discuss how we deal with the caveats of the models. In section III, we explain the data we use, and then in section IV we present estimation results. We end with conclusions in section $\mathrm{V}$. 


\section{Estimation Models and Several Remarks}

\section{A. Estimation Model of Frisch Elasticity}

In this section, based on the work of Browning, Hansen, and Heckman (1999), Blundell and MaCurdy (1999), and MaCurdy (1981), we define our empirical model for Frisch elasticity.

Consider a maximization problem for an individual who maximizes the utility function $U$ in equation (1) subject to the budget constraint in equation (2).

$$
\begin{aligned}
& U=\sum_{t} \beta^{t} U\left(c_{t}, h_{t}, x_{t}\right), \\
& a_{t+1}-a_{t}=r_{t} a_{t}+w_{t} h_{t}-p_{t} c_{t}+y_{t},
\end{aligned}
$$

where $\beta$ is the discount rate in period $t, c_{t}$ is consumption, $h_{t}$ is hours of work, $x_{t}$ is individual attributes that contains shift variables that affect utility, $a_{t}$ is assets, $r_{t}$ is the real interest rate, $w_{t}$ is real wages, $p_{t}$ is the price of consumer goods, and $y_{t}$ is non-wage income. For simplification, we assume that the utility function is additively separable between periods and that there is no uncertainty.

The first-order conditions for this intertemporal utility maximization problem, assuming an interior solution, are given by equations (3) to (5).

$$
\begin{aligned}
& U_{c}\left(c_{t}, h_{t}, x_{t}\right)=\lambda_{t} p_{t}, \\
& U_{h}\left(c_{t}, h_{t}, x_{t}\right)=-\lambda_{t} w_{t}, \\
& \lambda_{t}=\beta\left(1+r_{t}\right) \lambda_{t+1},
\end{aligned}
$$

where $\lambda_{t}$ is the marginal utility of wealth. Solving these first-order conditions for consumption $c_{t}$, hours of work $h_{t}$, and the marginal utility of wealth $\lambda_{t}$, as shown in equations (6) to (8), gives us the Euler equations for consumption, for hours of work (the labor supply function), and for the marginal utility of wealth (equation of motion).

$$
\begin{aligned}
& c_{t}=c\left(p_{t}, w_{t}, x_{t}, \lambda_{t}\right), \\
& h_{t}=h\left(p_{t}, w_{t}, x_{t}, \lambda_{t}\right),
\end{aligned}
$$




$$
\lambda_{t}=\lambda_{t+1}+\kappa_{t}
$$

where we express each variable in natural logarithmic form and set $\kappa_{t}=\ln \left(\beta\left(1+r_{t}\right)\right)$.

Using equation (7), we define Frisch elasticity as follows.

$$
\eta_{f}=\left.\frac{\partial h_{t}}{\partial w_{t}}\right|_{\lambda}=h_{w}=\frac{\partial h\left(p_{t}, w_{t}, x_{t}, \lambda_{t}\right)}{\partial w_{t}} .
$$

This elasticity expresses the marginal change in hours of work caused by marginal change in wages in period $t$, holding constant the current marginal utility of wealth $\lambda t$. Although Frisch elasticity can be obtained by estimating equation (7), the estimation cannot be performed directly because equation (7) includes an unobservable variable, the marginal utility of wealth $\lambda$.

We therefore employ the method shown by MaCurdy (1981) and Blundell and MaCurdy (1999). ${ }^{6}$ Specifically, we transform the Euler equation (8) for the marginal utility of wealth $\lambda_{t}$ to equation (8'), and then substitute it into (7) to get our estimation equation (9).

$$
\begin{aligned}
\lambda_{t} & =\lambda_{t-1}-\kappa_{t-1}+v_{t} \\
& =\lambda_{0}-\sum_{j=1}^{t} \kappa_{j-1}+\sum_{j=1}^{t} v_{t} \approx \lambda_{0}+b t+\sum_{j=1}^{t} v_{t}=\rho q+b t+\sum_{j=1}^{t} v_{t}, \\
h_{t} & =h\left(p_{t}, w_{t}, x_{t}, t, q, m_{t}\right),
\end{aligned}
$$

where $v_{t}$ is the moments of the forecast error on $\lambda_{t}, q$ is a vector of variable that determines $\lambda_{0}$ (the initial value of $\lambda_{t}$ ), and $\rho$ is its coefficient vector. For simplification, we assume $b \approx \bar{\kappa}=\ln (\beta(1+\bar{r}))$. We also added a control variable $m_{t}$ to account for the issues regarding the use of cross-sectional and aggregate data (we provide a detailed explanation of this control variable in Section III). Note that since we use cross-sectional data, $t$ signifies the age.

\footnotetext{
${ }^{6}$ As shown by MaCurdy (1981) and Altonji (1986), another method is to estimate a fixed effect model that eliminates $\lambda_{t}$ by substituting the difference of equation (8) for the difference of equation (7), but we do not use this method in this paper because we are unable to use longitudinal data.
} 
Equation (8') shows that the representative agent sets the initial value of the marginal utility of wealth $\lambda_{0}$ at age 0 , and then updates $\lambda_{t}$ with new information as the agent ages. We assume here that the initial value $\lambda_{0}$ is explained by a fixed effect $q$ that does not change with age. Accordingly, if a proper variable $q$ is found, we can obtain Frisch elasticity by estimating equation (9) using cross-sectional data.

In estimating equation (9), we conduct instrumental variable estimation with the instrumental variable $z_{t}$ (see Section III for the choice of instrument variables), to identify the labor supply function because wages are an endogenous variable.

\section{B. Several Remarks When Estimating Labor Supply Elasticity}

The above empirical model imposes several simplifying assumptions. In the following, we briefly describe how those assumptions may generate biases and show how we have chosen to deal with them in this paper.

\section{Liquidity Constraint}

Frisch elasticity under a life-cycle model implicitly assumes there is no liquidity constraint. When the liquidity constraint binds, however, the estimation bias arises. This is because if there is a liquidity constraint, an individual is subject both to the budget constraint in equation (2) and to the liquidity constraint $\left(a_{t}>0, \forall t\right)$ that wealth shall remain positive every period, in maximizing intertemporal utility of equation (1). Consequently, the Euler equation for the marginal utility of wealth in equation (8), also includes a marginal utility of borrowing $\varphi$. An estimate that does not consider the marginal utility of borrowing $\varphi$ in equation (8) may become inconsistent (Domeji and Floden [2002]).

To deal with the possible bias on Frisch elasticity due to ignorance of the liquidity constraint, we also estimate three other elasticities, the m-supply, Marshallian, and Hicksian elasticities. Since these three elasticities are intratemporal elasticities, they are robust to liquidity constraints. In addition, as explained below, they indicate the theoretical upper and lower bounds on Frisch elasticity, which are helpful in 
specifying the range of the Frisch elasticity. We briefly explain these three elasticities below.

\section{a. m-supply Elasticity}

Following Browning (1999) and Browning, Hansen, Heckman (1999), we use the term m-supply elasticity for the labor supply elasticity which holds the current period consumption constant. The m-supply elasticity can be derived as follows.

First, we solve the Euler equation for consumption (6) for marginal utility of wealth, and then substitute it into equation (7) to obtain equation (10) below.

$$
h_{t}=h\left(p_{t}, w_{t}, x_{t}, \lambda_{t}\right)=h^{c}\left(p_{t}, w_{t}, x_{t}, c_{t}\right)
$$

Using equation (10), m-supply elasticity is defined as below.

$$
\eta_{c}=\left.\frac{\partial h_{t}}{\partial w_{t}}\right|_{c}=h_{w}^{c}=\frac{\partial h^{c}\left(p_{t}, w_{t}, x_{t}, c_{t}\right)}{\partial w_{t}}
$$

This elasticity shows the marginal change in hours of work caused by marginal changes in current-period wages, assuming that current consumption is constant.

The relationship between m-supply elasticity and Frisch elasticity is given as follows. ${ }^{7}$

$$
h_{w}\left(p_{t}, w_{t}, x_{t}, \lambda_{t}\right)=h_{w}^{c}\left(p_{t}, w_{t}, x_{t}, c_{t}\right)+h_{c}^{c}\left(p_{t}, w_{t}, x_{t}, c_{t}\right) c_{w}\left(p_{t}, w_{t}, x_{t}, \lambda_{t}\right)
$$

where $h_{w}^{c}$ and $c_{w}$ are the derivatives of (10) and (6) with respect to wages. As is shown from equation (11), it is easier to estimate m-supply elasticity than Frisch elasticity, since it dose not contain the unobservable variable, the marginal utility of wealth. Furthermore, as already explained, m-supply elasticity is robust to the misspecification regarding the existence of a liquidity constraint since the estimation uses no information from the equation of motion (8) for the marginal utility of wealth.

\footnotetext{
7 See Browning, Hansen, and Heckman (1999).
} 
Now, if consumption and leisure are the substitutes and both are normal goods, then $h_{c}^{c} \leq 0$ and $c_{w}>0$, and therefore the second term on the right hand side of equation (11) becomes negative, indicating the relationship between m-supply elasticity $\eta_{c}$ and Frisch elasticity $\eta_{f}$ as $\eta_{f} \leq \eta_{c}$. In this case, m-supply elasticity gives an upper bound to Frisch elasticity (when $h_{c}^{c}>0$ and $c_{w}>0$, the second term on the right hand side becomes positive, and therefore m-supply elasticity becomes smaller than Frisch elasticity). Further, when consumption and hours of work are additively separable within periods, the second term on the right hand side becomes zero, so that m-supply elasticity equals Frisch elasticity.

In estimation, we add a vector of control variables $m_{t}$ to equation (10) to get the following estimation equation (12).

$$
h=h^{c}\left(p_{t}, w_{t}, x_{t}, c_{t}, m_{t}\right)
$$

As with equation (9), to remove the endogenity of wages and identify the labor supply function in equation (12), we use the instrumental variable $z_{t}$.

\section{b. Marshallian Elasticity}

The labor supply elasticity that holds the current period's net expenditures constant (instead of either consumption or the marginal utility of wealth) is called Marshallian elasticity, which is often used in analyses based on static models. The Marshallian elasticity can be derived as follows.

First, net expenditures (negative savings) $e_{t}$ is defined as follows (in levels).

$$
e_{t}=p_{t} c\left(p_{t}, w_{t}, x_{t}, \lambda_{t}\right)-w_{t} h\left(p_{t}, w_{t}, x_{t}, \lambda_{t}\right)=e\left(p_{t}, w_{t}, x_{t}, \lambda_{t}\right)
$$

Next, we solve this equation for marginal utility of wealth, and substitute the solution into equation (7) to obtain equation (14).

$$
h_{t}=h\left(p_{t}, w_{t}, x_{t}, \lambda_{t}\right)=h^{e}\left(p_{t}, w_{t}, x_{t}, e_{t}\right) .
$$

Using equation (14), Marshallian elasticity can be defined as below. 


$$
\eta_{e}=\left.\frac{\partial h_{t}}{\partial w_{t}}\right|_{e}=h_{w}^{e}=\frac{\partial h^{e}\left(p_{t}, w_{t}, x_{t}, e_{t}\right)}{\partial w_{t}} .
$$

This elasticity expresses the marginal change in hours of work caused by marginal changes in current-period wages, assuming current net expenditures is constant.

The relationship between Marshallian elasticity and Frisch elasticity is shown below. ${ }^{8}$

$$
h_{w}\left(p_{t}, w_{t}, x_{t}, \lambda_{t}\right)=h_{w}^{e}\left(p_{t}, w_{t}, x_{t}, e_{t}\right)+h_{e}^{e}\left(p_{t}, w_{t}, x_{t}, e_{t}\right) e_{w}\left(p_{t}, w_{t}, x_{t}, \lambda_{t}\right)
$$

where $h_{w}^{e}$ and $e_{w}$ are the derivatives of equations (14) and (13) with respect to wages, respectively.

If leisure is a normal good, then $h_{e}^{e} \leq 0$, and if savings tend to rise with increases in wages, then $e_{w} \leq 0$. In this case, the second term on the right hand side is positive, indicating the relation between Marshallian and Frisch elasticity as $\eta_{e} \leq \eta_{f}$.

For the estimation, we add a vector of control variables $m_{t}$ to equation (14) to get the following estimation equation (15).

$$
h=h^{e}\left(p_{t}, w_{t}, x_{t}, e_{t}, m_{t}\right)
$$

Once again, our estimation uses the instrumental variable $z_{t}$ to identify the labor supply function because wages are an endogenous variable.

\section{c. Hicksian Elasticity}

We look last at Hicksian elasticity, which is labor supply elasticity with utility held constant in a static model. Specifically, by applying the Slutsky equation to Marshallian elasticity with the income effect removed, Hicksian elasticity is expressed as follows.

$$
\eta_{h}=h_{w}^{e}-h_{e}^{e}\left(p_{t}, w_{t}, x_{t}, e_{t}\right) \theta
$$

\footnotetext{
${ }^{8}$ See Browning, Hansen, and Heckman (1999).
} 
where $\theta=w_{t} h_{t} / e_{t}$ (variables are defined in levels). It is well known that if leisure is a normal good, Hicksian elasticity is greater than Marshallian elasticity $\left(\eta_{e} \leq \eta_{h}\right)$. One can also show that Hicksian elasticity is smaller than, and can be a lower bound for, Frisch elasticity $\left(\eta_{h} \leq \eta_{f}\right){ }^{9} \quad$ Hicksian elasticity is obtained by transforming equation (16) using the estimation results from equation (15). As with m-supply elasticity, Marshallian and Hicksian elasticities are also robust to the liquidity constraint since the estimation uses no information from the equation of motion (8) for the marginal utility of wealth.

\section{Others}

Besides the liquidity constraint, there are three other issues we must consider when estimating our model; corner solutions, consumption-leisure separability, and unemployment.

First, we thus far have assumed a (representative) individual who chooses an interior solution for her supply of labor $\left(h_{t}>0\right)$. In reality, however, it is necessary to consider the possibility that some individuals may choose not working (the corner solution; $h_{t}=0$ ), which implies that we have to introduce heterogeneity among individuals.

For the estimation of labor supply elasticity using micro data containing heterogeneous individuals, the corner solution to equation (4) is often observed. In this case, one should clearly distinguish "the intensive margin,” which describes how the number of hours worked would change in response to a one percent wage change for those individuals choosing an interior solution, and "the extensive margin," which describes how many individuals would choose a corner solution (that is, how many would enter or exit the labor market)..$^{10}$

To deal with the corner solution problem, we define hours of work $h_{t}$ as man-hours at prefecture, age group, and sex level. This makes it possible for us to obtain the estimate of labor supply elasticity along both the intensive and extensive

\footnotetext{
9 See MaCurdy (1981).

10 The literature finds that the bulk of changes in labor supply come from the extensive margin rather than the intensive margin (Heckman [1978, 1993], and Blundell and MaCurdy [1999]), and that labor supply elasticity changes substantially depending on which of these are considered.
} 
margins as is done by Lucas and Rapping (1969). Since it is possible to interpret our aggregate data as reflecting the average changes in labor supply of heterogeneous individuals including both the intensive and extensive margins (Mulligan [2001]), labor supply elasticity can be estimated based on a life-cycle model that assumes an interior solution.

Second is the separability of the utility function. The utility function in equation (1) includes no assumptions on the separability of consumption and hours of work. This is because the size of the labor supply elasticity will differ depending on whether the utility function is separable, as described in the explanation of m-supply elasticity.

To avoid misspecifications in the utility function, we begin by estimating the labor supply function without assuming the separability of consumption and hours of work and then move on to test for separability by looking at the significance of the coefficient on prices $p_{t}$ following Ham and Reilly (2002). ${ }^{11}$

Last is the treatment of unemployment. In Japan, as pointed out by Kuroda and Yamamoto (2005), downward nominal wage rigidity may have caused involuntary unemployment in the late 1990s. To deal with the bias from the under reporting of labor supply (that is, the possibility that involuntary unemployment is counted as leisure instead of potential labor supply [Ham 1986]), we use the unemployment rate as a control variable when estimating the labor supply function.

\section{Data}

The main data we use for the estimation are the annual data aggregated by prefecture, age group, and sex from the Survey on Time Use and Leisure Activities (Ministry of Internal Affairs and Communications; MIAC) and the Basic Survey on Wage Structure (Ministry of Health, Labor, and Welfare; MHLW). The description of the data and definition of variables are as follows.

\footnotetext{
${ }^{11}$ For example, price $p_{t}$ is not included in the labor supply function in equation (9) when the utility function is separable in consumption and hours of work, while it is included when the utility function is not separable. Consequently, if we include price $p_{t}$, in the estimation equation for the labor supply function, we can assess separability by checking whether that parameter differs significantly from zero.
} 


\section{A. Hours of Work: Definitions in Datasets A and B}

For hours of work $h_{t}$, we use the total man-hour labor supply, that is, average hours of work per worker multiplied by the number of workers. Depending on the type of the data, we calculate hours of work $h_{t}$ in two alternative ways.

First, we use the data from the Survey on Time Use and Leisure Activities taken in 1991, 1996, and 2001. Combined with the other variables, which we explain further in the next section, we call them dataset A. The Survey on Time Use and Leisure Activities surveys individuals every five years on their employment status and how they spend their time during the day by asking them to keep time diaries. This survey provides certain advantages for analysis, because (1) it offers data broken down by prefecture, age group, and sex and (2) it includes data on a diverse range of individuals, including part-time employees and employees of small firms. The survey has several limitations, however, including that (1) it is only taken once every five years, thus for the analysis from the 1990s, only the years of 1991, 1996, and 2001 are available; (2) it breaks its age groups into broad 10-year increments from 15 to 65; (3) it includes not only paid working hours but also unpaid overtime; and (4) it does not distinguish self-employed from employed workers.

Another source of data for hours of work is the Basic Survey on Wage Structure from 1992 to 2001. Combined with the other variables, we call them dataset B. The Basic Survey on Wage Structure, an annual survey of business establishments on wages and hours of work, is beneficial to the analysis in several respects: (1) the data is broken down by prefecture, age group, and sex; (2) it offers a large sample and allows for observing annual changes, because it is taken annually; and (3) the age groups are in smaller 5-year increments from 20 to 65 . It has its own limitations, however, including (1) the exclusion of data on workers at small firms, since the survey is limited to business establishments with at least 10 employees, and (2) data on part-time employees by prefecture is only usable as an aggregate for female workers of all ages, thus there is no information by age for males or for females. Because of this, we apply the average hours of work by part-time employees for all ages to each age group. The average hours of work per employee is derived by taking the weighted average of hours of work for full-time and part-time employees using the ratio of part-time to full-time 
employees as weight. The ratio of part-time to full-time employees by prefecture, age group, and sex is calculated from the Employment Status Survey (MIAC). ${ }^{12}$

\section{B. Other Variables (Wages, Prices, Consumption, and Net Spending)}

For wages $w_{t}$, we use the annual earnings, which consists of regular salaries, bonuses and other allowances (overtime pay, assignment allowances, commuting allowances, and family allowances), and divide that by hours of work from the Basic Survey on Wage Structure to obtain an hourly wage for full-time employees. For part-time employees, the only data available is the average hourly wage for female employees of all ages. Therefore, we apply this average hourly wage to all age groups of part-time employees. The weighted average is again taken based on the ratio of part-time to full-time employees to obtain an hourly wage for all employees.

For prices $p_{t}$, we use the Consumer Price Index (CPI; MIAC) by prefecture. For consumption $c_{t}$, we use households' average monthly spending by prefecture taken from the Household Survey (MIAC). Net expenditures $e_{t}$ is the consumption less annual earnings divided by 12 months.

For the shift variable $x_{t}$ in the utility function, we use age (median value for each age group), the average number of household members by prefecture (from the Population Census; MIAC), the share of primary industry of each prefecture (calculated using the value-added base share in Annual reports on Prefectural Accounts; Cabinet Office), and year dummies. ${ }^{13}$ The average number of household members accounts for the possibility that labor supply decisions are made at the household level. ${ }^{14}$

For the variable $q$, which determines the initial value of the marginal utility of wealth, we use fixed effects by prefectures and by birth cohorts. For the instrument

\footnotetext{
${ }^{12}$ Because both the Employment Status Survey and the Population Census used for other variables are taken only once every five years, we use a linear extrapolation for those years with no survey.

${ }^{13}$ The impact from the reduction in the scheduled working hours in Japan from the end of the 1980s to the early 1990 is controlled by the year dummies.

${ }^{14}$ When considering labor supply on the household level, one should include hours of work and wages of other families, but since we use aggregate data here, we approximate those information by using the data on the number of individuals per household. Further, it has been noted that there is a possibility that Japan's income tax and social insurance schemes distort labor supply of workers (especially nonhousehold heads) with annual incomes of around one million yen. When using aggregate data, however, it is difficult to take into account, so our analysis disregards this possibility.
} 
variables $z_{t}$, we use tenure, tenure squared, the unemployment rate by region, age group, and sex (Labor Force Survey; MIAC), annual income per capita by prefecture (Annual Reports on Prefectural Accounts; Cabinet Office), CPI by prefecture, and year dummies.

The control variable $m_{t}$ includes the population share by prefecture and sex, and the age group share by prefecture and sex. We use these variables to adjust for the possibility that the total supply of man-hours may vary according to the population and age-group share. The population and age-group share are calculated using the Survey on Time Use and Leisure Activities for dataset A and the Basic Survey on Wage Structure and the Employment Status Survey (MIAC) for dataset B.

The control variable $m_{t}$ also includes the share of self-employed by region (Labor Force Survey) and the unemployment rate by region, age group, and sex. The share of self-employed is used to adjust for the lack of information on the wages of self-employed and the unemployment rate to adjust for involuntary unemployment.

\section{Estimation Results for Labor Supply Elasticity}

Using the above data, we estimate labor supply elasticity. Table 1 shows the summary statistics for each variable used in the estimation. We use equations (9), (12), and (15) in log linear form to estimate Frisch, m-supply, and Marshallian elasticities respectively. Tables 2 to 5 and Figures 1 to 2 show the estimation results. We explain our results below, focusing on (1) the level of labor supply elasticity (Tables 2 to 5) and (2) possible changes in Frisch elasticity in the 1990s (Figures 1 to 2).

\section{A. The Level of Labor Supply Elasticity}

\section{The Case Using Dataset A}

Estimation based on dataset A is done by pooling 750 samples from 1991, 1996, and 2001. The results are shown in Tables 2 and 3. Table 2 is the estimation result for both sexes, males, and females by defining hours of work $h_{t}$ as the total labor supplied in man-hours. The parameters on wages (in log term) in this table give labor supply 
elasticity on the intensive and extensive margins combined. Table 3 is the estimation result by defining hours of work $h_{t}$ as the hours of work per worker. Therefore, parameters on wages in this table give labor supply elasticity on only the intensive margin.

Looking at Table 2 (1) for both sexes, we obtain the estimates of elasticity on extensive and intensive margins combined is 0.67 for Frisch, 0.63 for m-supply, 0.47 for Marshallian, and 0.48 for Hicksian. ${ }^{15}$ A test for the difference shows no statistically significant difference between the Frisch and m-supply elasticities. This may reflect the estimation result that consumption is not statistically significant in equation (12). Considering further the estimate of Hicksian elasticity, we can see that Frisch elasticity would be in the range of 0.5 to 0.7 , even in the presence of a liquidity constraint. Note that the estimated Marshallian and Hicksian elasticities are roughly the same value (smaller than both Frisch and m-supply elasticities), implying a small income effect.

As for the other variables, all of the parameters for the CPI are significantly negative, suggesting that leisure and consumption are not separable in the utility function. The unemployment parameter is significantly negative, suggesting there is a need to consider the possibility of involuntary unemployment. The parameters for both population share and age group share are significant, suggesting the need to estimate labor supply elasticity after eliminating the impact from differences in population share across prefectures and from the aging of the population. It should be worth noting that the estimates of labor supply elasticity become larger if we eliminate the unemployment rate and age group share. In other words, estimates of labor supply elasticity would be overestimated if we only look at the aggregate wage-labor-supply relationships measured by wages and man-hours, and ignore unemployment and population aging. ${ }^{16}$ In general, wages in Japan tend to increase with age. Thus, the aging of Japan's population causes both the increase in aggregate labor supply in

\footnotetext{
${ }^{15}$ Although not shown here, there is a tendency for elasticities to be overestimated when instrumental variables are not used.

${ }^{16}$ For these variables, similar results were obtained throughout Tables 2 to 5 . Note that neither population share nor age group share is included in the estimation equations for labor supply elasticity on only the intensive margin shown in Tables 3 and 5.
} 
man-hours bases and the increase in aggregate (average) wage both for old generations, which would bring about upper-bias in labor supply elasticity.

In Table 2 (2) showing the estimation results by sex, ${ }^{17}$ we observe a large difference in Frisch elasticity between the sexes. Specifically, males have a small Frisch elasticity of 0.20 , versus a large 1.53 for females. These results suggest that when estimating labor supply elasticity for both sexes, the aggregation bias would be severe, as pointed out by Browning, Hansen, and Heckman (1999). In other words, it may be difficult to accurately describe people's labor supply behavior by using a standard macro model assuming a representative agent.

Table 3 (1) gives the estimate of elasticity on only the intensive margin (excluding the extensive margin) of 0.19 for both Frisch and m-supply, -0.01 for Marshallian, and 0.1 for Hicksian. ${ }^{18}$ These results suggest that Frisch elasticity on only the intensive margin is less than 0.2 , considerably lower than on both margins combined. This means that in Japan, as well, most of the change in labor supply reflects the extensive margin, as pointed out for the US labor market by Heckman (1978, 1993) and Blundell and MaCurdy (1999).

The estimates by sex in Table 3 (2) show Frisch elasticities of 0.24 for males and 0.10 for females. Although there are also differences between the sexes in Frisch elasticity on the intensive margin only, elasticity is small for both males and females.

\section{The Case Using Dataset B}

Estimations based on dataset B are done by pooling 4,653 samples from 1992 to 2002. The results are shown in Tables 4 and 5 . Table 4 is the estimation result for both sexes, males, and females by defining hours of work $h_{t}$ as the total labor supplied in man-hours. The estimates give labor supply elasticity on both the intensive and extensive margins.

\footnotetext{
17 We omit our estimations for equations (12) and (15), since the data needed for the estimation, consumption and net spending, is only available on the household level. Consequently, for the estimation by sex, only Frisch elasticity is shown in Tables 2 (2), 3 (2), 4 (2), and 5 (2).

18 Because the dependent variable here is hours of work per worker by prefecture, age group, and sex, it creates the heteroskedascity problem, in which the variance of the error term becomes smaller as the number of workers in the group increases. We therefore use a weighted least squares estimation, with the number of workers as the weight (the same for Table 5 below).
} 
Table 5 is the estimation result by defining hours of work $h_{t}$ as the hours of work per worker. The estimates give labor supply elasticity on only the intensive margin.

Looking at Table 4 (1) for both sexes, we obtain the estimates of elasticity on the intensive and extensive margins combined as 0.97 for Frisch, 0.78 for m-supply, 0.63 for Marshallian, and 0.78 for Hicksian. The smaller m-supply elasticity relative to Frisch elasticity may be attributed to the second term on the right hand side of equation (11) being positive, because the parameters of the consumption in estimation equation (12) are significantly positive. ${ }^{19}$ In this case, the lower bound on Frisch elasticity is given by either m-supply or Hicksian elasticity. Thus, Frisch elasticity would be about 0.8 to 1.0 , even under a liquidity constraint, roughly the same as the results obtained from dataset A.

The estimates of Frisch elasticity by sex in Table 4 (2) show 0.69 for males and 1.26 for females, which are higher than those estimated from dataset A, particularly for males. However, this result again indicates a large difference between the sexes.

Finally, Table 5 shows estimates of labor supply elasticity on only the intensive margin by using hours of work per worker as the dependent variable. Table 5 (1) gives elasticity estimates of 0.10 for Frisch and 0.11 for m-supply, Marshallian, and Hicksian. The estimates by sex in Table 5 (2) show Frisch elasticities of 0.14 for males and 0.13 for females. Accordingly, as with the estimates using dataset A, Frisch elasticity on only the intensive margin is small at about 0.1, implying that the hours of work by already employed workers are not very sensitive to wage changes.

\section{B. Changes in Frisch elasticity}

Lastly, we examine the possible changes in Frisch elasticity during the estimation period, essentially the 1990s. Specifically, we add in cross terms for wages and the year dummies in equation (9) to take into account the possibility of changes in Frisch elasticity estimations.

\footnotetext{
${ }^{19}$ Nevertheless, as described in Section II, since in general leisure and consumption are normally the substitutes and both are considered normal goods, the second term on the right hand side of equation (11) shall be negative, and thus m-supply gives the upper bound for Frisch elasticity. This indicates that our estimation results probably need to be interpreted broadly.
} 
Using our estimation results, we plot Frisch elasticity for each year and the $90 \%$ confidence interval in Figures 1 and 2 (the bold line shows Frisch elasticity and the thin line the $90 \%$ confidence interval). Figures 1 and 2 show the results for dataset $\mathrm{A}$ and $\mathrm{B}$, respectively. The Frisch elasticities for both the intensive and extensive margins combined and the intensive margin only are plotted.

Figure 1 (1), based on dataset A, shows a declining trend in Frisch elasticity for both sexes on both margins combined in 1991, 1996, and 2001. By sex, there is a declining trend for males, and a rising trend for females from 1996 to 2001. For females, however, since the statistical significance is low, we regard the elasticity as unchanged. The Frisch elasticity on only the intensive margin given in Figure 1 (2) is fairly unchanged for males, but shows a notable increase for females from 1991 to 2001. The fact that Frisch elasticity on both the extensive and intensive margins is in a declining trend for males and unchanged for females, and that Frisch elasticity on only the intensive margin is unchanged for males and rising for females, suggests the possibility that Frisch elasticity on only the extensive margin followed a declining trend for both sexes in the 1990s.

Looking next at Figure 2 (1), which is based on dataset B, we see a slightly rising trend in Frisch elasticity for both sexes on both margins from 1997. Looked at by sex, however, neither males nor females show any change in elasticity over the estimation period. $^{20}$ Frisch elasticity on only the intensive margin given in Figure 2 (2) shows a rising trend for both sexes from 1997. There is a slight rising trend for males from 1997, while for females elasticity is significantly higher in 2002 than in 1992 . These results also suggest the possibility that for dataset B, as well, Frisch elasticity on only the extensive margin followed a declining trend for both sexes.

\section{Concluding Remarks}

In this paper, using Japanese data from the 1990s aggregated by prefecture, age group, and sex, we estimate the plausible range of Frisch elasticity, one measure of intertemporal labor supply elasticity.

\footnotetext{
${ }^{20}$ Although there was an increase for females from 1998, it was not considered statistically significant because of the wide $90 \%$ confidence interval for the estimates.
} 
Our estimation results are as follows. First, Frisch elasticity on the extensive and intensive margins combined is in the range of 0.7 to 1.0 when we pool data on males and females together (in our paper, we call this "both sexes"). We conclude that our estimates of Frisch elasticity are not very different from the estimates suggested in the US empirical studies, such as Lucas and Rapping (1969), Algoskoufis (1987) and Mulligan (1999). Second, we find large differences in Frisch elasticity by sex, with males having elasticity in the range of 0.2 to 0.7 , and females in the range of 1.3 to 1.5 . Third, Frisch elasticity on the intensive margin only is very low for both sexes, males, and females, in the range of 0.1 to 0.2. The last finding is consistent with Heckman (1993), that extensive margin dominates intensive margin in most of the changes in labor supply behavior.

Regarding the possible changes in Frisch elasticity in the 1990s, it has been either unchanged or slightly declining on the extensive and intensive margins combined, although it was either unchanged or slightly rising on the intensive margin and possibly declining on the extensive margin. These changes may be generated by the increase in part-time workers. In Japan, there is a huge discrepancy between full-time and part-time hourly wages even after controlling for individual attributes. The substantial increase in the ratio of part-time workers since 1990s, therefore, may influence our results to some extent. An analysis using longitudinal data is needed to check this possibility $^{21}$. There is also a possibility that the life-cycle model does not hold up, which suggests another issue for further study: an estimation of labor supply elasticities based on other theoretical models.

\footnotetext{
${ }^{21}$ Kuroda and Yamamoto (2007) investigate this possibility using individual longitudinal data (Japanese Panel Survey of Consumers of the Institute for Research on Household Economics <IRHE >) for young females aged 20 to 30s. They show that young female's extensive margin has decreased in the late 1990s, which is consistent with this paper's finding. IRHE is the only Japanese individual longitudinal data available to researchers upon application, which provides information since 1993. However, this survey limits its sample to females who were in the 24-34 age groups in 1993, and thus not appropriate to estimate a representative agent's elasticity for Japan. Estimating other groups such as young men or elderly remains as a future task.
} 


\section{References}

Altonji, Joseph G., “The Intertemporal Substitution Model of Labour Market Fluctuations: An Empirical Analysis,” Review of Economic Studies, 49(5), 1982, pp.783-824.

- "Intertemporal Substitution in Labor Supply: Evidence from Micro Data," Journal of Political Economy, 94(3-2), 1986, pp.S176-215.

Algoskoufis, George S., “On Intertemporal Substitution and Aggregate Labor Supply,” Journal of Political Economy, 95(5), 1987, pp.938-960.

Blundell, Richard and Thomas MaCurdy, "Labor Supply: A Review of Alternative Approaches,” in Orley Ashenfelter and David Card, eds. Handbook of Labor Economics, Vol.3, 1999, pp.1559-1695.

Browning, Martin, "Modeling Commodity Demands and Labour Supply with M-Demands,” Discussion Papers: 99-08, Institute of Economics, University of Copenhagen, 1999.

—, Angus Deaton, and Margaret Irish, “A Profitable Approach to Labor Supply and Commodity Demands over the Life-Cycle,” Econometrica, 53(3), 1985, pp.503-544.

—, Lars Peter Hansen, and James J. Heckman, "Micro Data and General Equilibrium Models,” in John B. Taylor and Michael Woodford, eds. Handbook of Macroeconomics, Vol. 1A, 1999, pp.543-633.

Domeij, David, and Martin Floden, "The Labor-supply Elasticity and Borrowing Constraints: Why Estimates are Biased?," Review of Economic Dynamics, 9(2), 2006, pp.242-262.

Friedman, Milton, A Theory of Consumption Function, Aldine Publishing Company, 1957.

- Price Theory, Aldine Publishing Company, 1976.

Ham, John C., "Testing Whether Unemployment Represents Intertemporal Labour Supply Behavior,” Review of Economic Studies, 53(4), 1986, pp.559-578.

— , and Kevin T. Reilly, "Testing Intertemporal Substitution, Implicit Contracts, and Hours Restriction Models of the Labor Market Using Micro Data," American Economic Review, 92(4), 2002, pp.905-927.

Hansen, Gary, D., "Indivisible Labor and the Business Cycle,” Journal of Monetary Economics, 16(3), 1985, pp.309-327.

Hayashi, Fumio, and Edward C. Prescott, “The 1990s in Japan: A Lost Decade,” Review of Economic Dynamics, 2002, pp.206-235. 
Heckman, James J., “A Partial Survey of Recent Research on the Labor Supply of Women,” American Economic Review, 68(2), 1978, pp.200-207.

— , "What Has Been Learned About Labor Supply in the Past Twenty Years?," American Economic Review, 83(2), 1993, pp.116-121.

— Labour Supply,” Review of Economic Studies, 49(4), 1982, pp.659-660.

King, Robert G., and Sergio T. Rebelo, "Resuscitating Real Business Cycles,” in John B.

Taylor and Michael Woodford, eds. Handbook of Macroeconomics, Volume 1B, 1999, pp.927-1007.

Kuroda, Sachiko and Isamu Yamamoto, "Wage Fluctuations in Japan after the Burst of the Bubble: Downward Nominal Wage Rigidity, Payroll, and the Unemployment Rate,” Monetary and Economic Studies, 23 (2), Institute for Monetary and Economic Studies, Bank of Japan, 2005, pp.1-30.

, and —- "How has Frisch Labor Supply Elasticity Changed during the 1990s in Japan? - Analysis from Micro and Macro Perspectives,” Discussion Paper Series, No. 339, Project on Intergenerational Equity and Center for Intergenerational Studies, Institute of Economic Research, Hitotsubashi University, 2007 (in Japanese).

Lucas, Robert E. Jr., and Leonard A. Rapping, "Real Wages, Employment, and Inflation,” Journal of Political Economy, 77(5), 1969, pp.721-754.

MaCurdy, Thomas, E., “An Empirical Model of Labor Supply in a Life-Cycle Setting,” Journal of Political Economy, 89(6), 1981, pp.1059-1085.

Mulligan, Casey, B., "Substitution Over Time: Another Look at Life Cycle Labor Supply,” NBER Macroecnomics Annual 1998, Ben S. Bernanke and Julio Rotemberg eds., The MIT Press, 1999.

—, "Aggregate Implication of Indivisible Labor," Advances in Macroeconomics, 1(1), article 4. 2001.

Mankiw, N. Gregory, Julio J. Rotemberg, and Lawrence H. Summers, "Intertemporal Substitution in Macroeconomics," Quarterly Journal of Economics, 100, 1985, pp.225-251.

Osano, Hiroshi, and Tohru Inoue, "Testing between Competing Models of Real Business Cycles,” International Economic Review, 32(3), 1991, pp.669-688.

Prescott, Edward C., “Theory Ahead of Business Cycle Measurement,” Quarterly Review, Federal Reserve Bank of Minneapolis, 10(4), 1986, pp.9-22.

Rogerson, Richard, “Indivisible Labor, Lotteries and Equilibrium,” Journal of Monetary Economics, 21(1), 1988, pp.3-16. 
Rotemberg, Julio and Michael Woodford, "An Optimization-Based Econometric Framework for the Evaluation of Monetary Policy", NBER Macroeconomics Annual 1997, The MIT Press, 1998, pp.297-346.

Sakura, Kenichi, Hitoshi Sasaki, and Masahiro Higo, “1990 Nendaino Nihonno Keizaihendou - Facto Fainding (Economic Fluctuation in Japan during 1990s -fact finding)," Working Paper Series, 05-J-10, Bank of Japan, 2005 (in Japanese). 
Table 1 Summary Statistics: Dataset A

\section{(1) Dataset A}

\begin{tabular}{|c|c|c|c|c|c|c|}
\hline & \multicolumn{2}{|c|}{ Both sexes } & \multicolumn{2}{|c|}{ Males } & \multicolumn{2}{|c|}{ Females } \\
\hline & Means & $\begin{array}{c}\text { Standard } \\
\text { errors }\end{array}$ & Means & $\begin{array}{l}\text { Standard } \\
\text { errors }\end{array}$ & Means & $\begin{array}{l}\text { Standard } \\
\text { errors }\end{array}$ \\
\hline Hours of work per day) & 6.31 & 0.44 & 7.03 & 0.61 & 5.36 & 0.57 \\
\hline Wage per hour; 100 yen) & 16.66 & 4.09 & 20.09 & 6.06 & 11.81 & 1.63 \\
\hline Tenure (years) & 9.68 & 4.39 & 11.60 & 5.97 & 7.03 & 2.47 \\
\hline Unemployment rate by region and sex (\%) & 3.88 & 2.49 & 4.12 & 2.68 & 3.63 & 2.48 \\
\hline Income per capita by prefecture ( 1,000 yen) & 3550.64 & 700.68 & 3550.64 & 700.68 & 3550.64 & 700.68 \\
\hline CPI by prefecture (year 1995=100) & 101.35 & 3.46 & 101.35 & 3.46 & 101.35 & 3.46 \\
\hline Number of household members & 2.93 & 0.27 & 2.93 & 0.27 & 2.93 & 0.27 \\
\hline Share of self-employed by region & 0.20 & 0.04 & 0.20 & 0.04 & 0.20 & 0.04 \\
\hline Share of primary industry by prefecture & 0.03 & 0.02 & 0.03 & 0.02 & 0.03 & 0.02 \\
\hline Consumption (per household, per month; 100 yen) & 3413.95 & 276.63 & 3413.95 & 276.63 & 3413.95 & 276.63 \\
\hline Number of Samples & 705 & & 705 & & 705 & \\
\hline
\end{tabular}

\section{(2) Dataset B}

\begin{tabular}{|c|c|c|c|c|c|c|}
\hline & \multicolumn{2}{|c|}{ Both sexes } & \multicolumn{2}{|c|}{ Males } & \multicolumn{2}{|c|}{ Females } \\
\hline & Means & $\begin{array}{c}\text { Standard } \\
\text { errors }\end{array}$ & Means & $\begin{array}{c}\text { Standard } \\
\text { errors }\end{array}$ & Means & $\begin{array}{c}\text { Standard } \\
\text { errors }\end{array}$ \\
\hline Hours of work per month) & 167.45 & 23.76 & 178.41 & 17.94 & 152.09 & 38.03 \\
\hline Wage per hour; 100 yen) & 17.57 & 4.10 & 21.34 & 6.15 & 12.27 & 1.65 \\
\hline Tenure (years) & 10.22 & 4.23 & 12.30 & 5.96 & 7.40 & 2.23 \\
\hline Unemployment rate by region and sex (\%) & 3.50 & 2.51 & 3.79 & 3.12 & 3.03 & 2.79 \\
\hline Income per capita by prefecture (1,000 yen) & 3588.17 & 681.48 & 3588.17 & 681.48 & 3588.17 & 681.48 \\
\hline CPI by prefecture (year 1995=100) & 102.79 & 3.30 & 102.79 & 3.30 & 102.79 & 3.30 \\
\hline Number of household members & 2.90 & 0.25 & 2.90 & 0.25 & 2.90 & 0.25 \\
\hline Share of self-employed by region & 0.19 & 0.03 & 0.19 & 0.03 & 0.19 & 0.03 \\
\hline Share of primary industry by prefecture & 0.03 & 0.02 & 0.03 & 0.02 & 0.03 & 0.02 \\
\hline Consumption (per household, per month; 100 yen) & 3482.29 & 297.86 & 3482.29 & 297.86 & 3482.29 & 297.86 \\
\hline Number of Samples & 4,653 & & 4,653 & & 4,653 & \\
\hline
\end{tabular}


Table 2 Estimation Results for Labor Elasticity (Intensive and Extensive Margins Combined): Dataset A

\section{(1) Both sexes}

\begin{tabular}{|c|c|c|c|c|c|c|}
\hline & \multicolumn{2}{|c|}{ Equation (9) } & \multicolumn{2}{|c|}{ Equation (12) } & \multicolumn{2}{|c|}{ Equation (15) } \\
\hline & parameters & $\overline{t \text { statistics }}$ & parameters & $t$ statistics) & parameters & statistics) \\
\hline & 0.67 & $(12.12)$ & 0.63 & $(6.24)$ & 0.47 & $(3.38)$ \\
\hline Age (years) & -0.01 & $(-6.05)$ & -0.01 & $(-4.94)$ & 0.00 & $(-3.56)$ \\
\hline CPI (log term) & -1.57 & $(-2.23)$ & -5.96 & $(-9.71)$ & -5.41 & $(-7.96)$ \\
\hline Unemployment rate & -0.05 & $(-10.56)$ & -0.06 & $(-6.07)$ & -0.06 & $(-6.04)$ \\
\hline Number of household members & -0.13 & $(-0.47)$ & -0.05 & $(-0.91)$ & -0.05 & $(-0.89)$ \\
\hline Share of self-employed & 0.44 & $(0.52)$ & -2.12 & $(-4.42)$ & -1.67 & $(-3.17)$ \\
\hline Share of primary industry & 2.24 & $(1.46)$ & -1.61 & $(-2.11)$ & -1.39 & $(-1.73)$ \\
\hline Population share by prefecture and sex & 4.90 & (21.68) & 4.93 & $(10.52)$ & 4.79 & ( 8.99) \\
\hline Age group share & 10.33 & $(0.80)$ & 35.04 & (33.35) & 36.25 & $(29.00)$ \\
\hline Consumption (log term) & & & -0.18 & $(-1.21)$ & & \\
\hline Net Expenditures (log term) & & & & & -0.05 & $(-2.40)$ \\
\hline Constant & 12.80 & $(3.28)$ & 33.56 & $(12.68)$ & 30.17 & $(10.30)$ \\
\hline Other control variables & $\begin{array}{r}\text { year, pre } \\
\text { birth cohor }\end{array}$ & $\begin{array}{l}\text { ecture, } \\
\text { dummies }\end{array}$ & year dur & Imies & year du & mies \\
\hline R-squared & 0.9 & & 0.8 & & $0 . \varepsilon$ & \\
\hline $\begin{array}{l}\text { Labor supply elasticities } \\
\end{array}$ & $\begin{array}{c}\text { Frisch e } \\
0.67\end{array}$ & $\begin{array}{l}\text { sticity } \\
\text { ( 12.12) }\end{array}$ & $\begin{array}{r}\text { m-supply } \\
0.63\end{array}$ & $\begin{array}{l}\text { asticity } \\
\text { ( } 6.24)\end{array}$ & $\begin{array}{r}\text { Marshalia } \\
0.47 \\
\text { Hicksian }\end{array}$ & $\begin{array}{l}\text { elasticity } \\
\qquad \text { ( } 3.38) \\
\text { asticity }\end{array}$ \\
\hline & & & & & 0.48 & $(3.60)$ \\
\hline
\end{tabular}

\section{(2) By Sex}

\begin{tabular}{lrrrrr}
\hline & \multicolumn{2}{c}{ Males } & & \multicolumn{2}{c}{ Females } \\
\cline { 2 - 3 } \cline { 5 - 6 } & parameters $(t$ statistics $)$ & parameters $(t$ statistics) \\
\hline \hline Wage (log term) & 0.20 & $(3.68)$ & 1.53 & $(15.48)$ \\
Age (years) & 0.00 & $(0.70)$ & -0.01 & $(-4.33)$ \\
CPI (log term) & 1.24 & $(1.39)$ & -3.91 & $(-4.39)$ \\
Unemployment rate & -0.09 & $(-13.13)$ & -0.03 & $(-6.14)$ \\
Number of household members & -0.19 & $(-0.49)$ & 0.13 & $(0.41)$ \\
Share of self-employed & 2.15 & $(1.95)$ & 0.17 & $(0.15)$ \\
Share of primary industry & 4.60 & $(2.27)$ & 2.53 & $(1.37)$ \\
Population share by prefecture and sex & 3.99 & $(14.06)$ & 7.72 & $(32.64)$ \\
Age group share & 9.09 & $(0.63)$ & 16.29 & $(1.32)$ \\
Constant & 0.53 & $(0.11)$ & 18.94 & $(4.10)$ \\
\hline Other control variables & \multicolumn{3}{c}{ year, prefecture, } & year, prefecture, \\
& birth cohort dummies & birth cohort dummies \\
\hline R-squared & \multicolumn{3}{c}{0.97} & \multicolumn{3}{c}{0.97} \\
\hline \hline Labor supply elasticities & \multicolumn{3}{c}{ Frisch elasticity } & Frisch elasticity \\
& 0.20 & $(3.68)$ & & 1.53 & $(15.48)$ \\
\hline
\end{tabular}


Table 3 Estimation Results for Labor Elasticity (Intensive Margin): Dataset A

\section{(1) Both sexes}

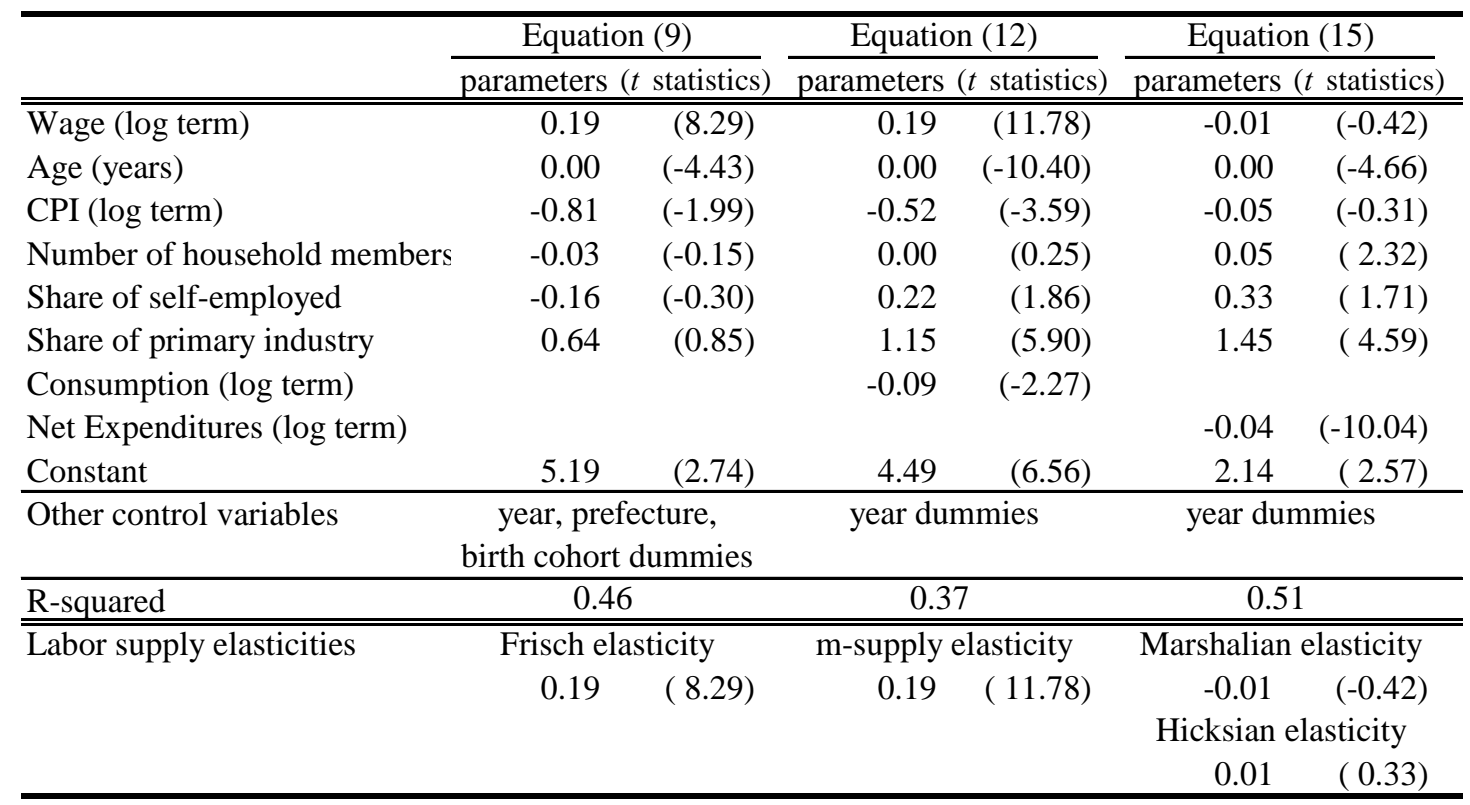

\section{(2) By Sex}

\begin{tabular}{lrrrrr}
\hline & \multicolumn{2}{c}{ Males } & & \multicolumn{2}{c}{ Females } \\
\cline { 2 - 3 } \cline { 5 - 6 } & parameters $(t$ statistics) & parameters $(t$ statistics) \\
\hline \hline Wage (log term) & 0.24 & $(14.90)$ & & 0.10 & $(1.64)$ \\
Age (years) & 0.00 & $(-5.19)$ & & 0.00 & $(-1.46)$ \\
CPI (log term) & -0.33 & $(-0.75)$ & -1.06 & $(-1.90)$ \\
Number of household members & 0.07 & $(0.40)$ & & 0.12 & $(0.59)$ \\
Share of self-employed & -0.23 & $(-0.40)$ & -0.28 & $(-0.47)$ \\
Share of primary industry & 1.41 & $(1.52)$ & 0.47 & $(0.45)$ \\
Constant & 2.67 & $(1.32)$ & 6.10 & $(2.31)$ \\
\hline Other control variables & year, prefecture, & year, prefecture, \\
& birth cohort dummies & birth cohort dummies \\
\hline R-squared & \multicolumn{3}{c}{0.55} & \multicolumn{3}{c}{0.64} \\
\hline \hline Labor supply elasticities & \multicolumn{3}{c}{ Frisch elasticity } & Frisch elasticity \\
& \multicolumn{3}{c}{0.24} & $(14.90)$ & \multicolumn{3}{c}{0.10} & $(1.64)$ \\
\hline
\end{tabular}




\section{Table 4 Estimation Results for Labor Elasticity (Intensive and Extensive Margins Combined): Dataset B}

\section{(1) Both sexes}

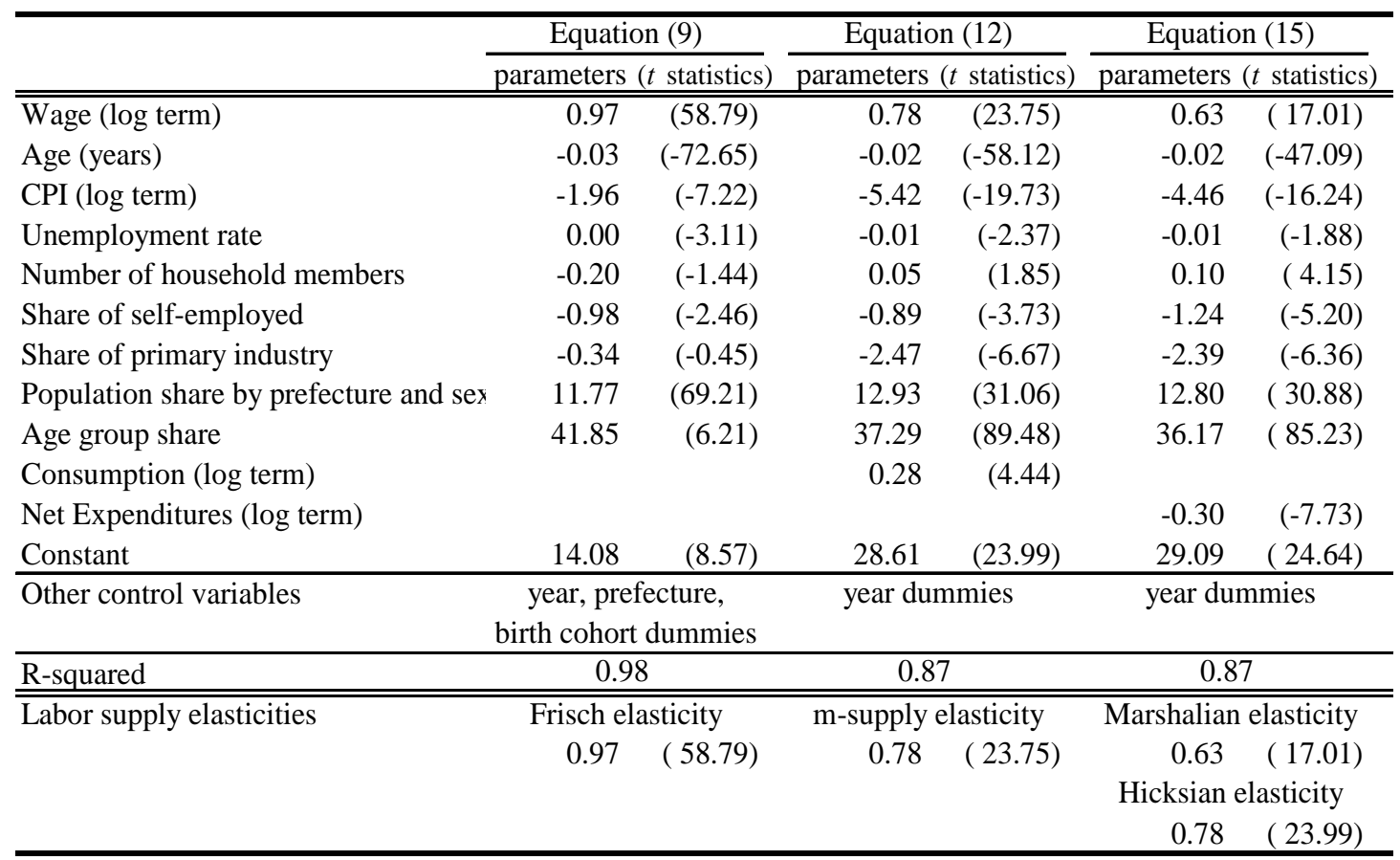

\section{(2) By Sex}

\begin{tabular}{|c|c|c|c|c|}
\hline & \multicolumn{2}{|c|}{ Males } & \multicolumn{2}{|c|}{ Females } \\
\hline & parameters & $\overline{t \text { statistics) }}$ & parameters & $t$ statistics) \\
\hline 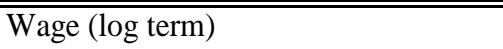 & 0.69 & (37.56) & 1.26 & (14.09) \\
\hline Age (years) & -0.03 & $(-69.62)$ & -0.02 & $(-27.16)$ \\
\hline CPI (log term) & -1.07 & $(-3.76)$ & -2.55 & $(-4.18)$ \\
\hline Unemployment rate & -0.01 & $(-3.50)$ & -0.02 & $(-9.23)$ \\
\hline Number of household members & -0.33 & $(-2.24)$ & 0.42 & $(1.37)$ \\
\hline Share of self-employed & -1.34 & $(-3.45)$ & -0.54 & $(-0.61)$ \\
\hline Share of primary industry & -1.63 & $(-2.19)$ & 1.19 & $(0.75)$ \\
\hline Population share by prefecture and ses & 8.94 & $(52.97)$ & 19.25 & $(52.59)$ \\
\hline Age group share & 53.03 & $(7.42)$ & 27.41 & $(1.93)$ \\
\hline Constant & 9.70 & $(5.57)$ & 14.32 & $(4.02)$ \\
\hline Other control variables & $\begin{array}{r}\text { year, pre } \\
\text { birth cohor }\end{array}$ & $\begin{array}{l}\text { ecture, } \\
\text { dummies }\end{array}$ & $\begin{array}{r}\text { year, pref } \\
\text { birth cohort }\end{array}$ & $\begin{array}{l}\text { ecture, } \\
\text { dummies }\end{array}$ \\
\hline R-squared & 0.9 & & 0.91 & \\
\hline Labor supply elasticities & $\begin{array}{c}\text { Frisch el } \\
0.69 \\
\end{array}$ & $\begin{array}{l}\text { sticity } \\
(37.56)\end{array}$ & $\begin{array}{c}\text { Frisch el } \\
1.26\end{array}$ & $\begin{array}{l}\text { ssticity } \\
(14.09)\end{array}$ \\
\hline
\end{tabular}


Table 5 Estimation Results for Labor Elasticity
(Intensive Margin): Dataset B

\section{(1) Both sexes}

\begin{tabular}{|c|c|c|c|c|c|}
\hline & \multicolumn{2}{|c|}{ Equation (9) } & \multicolumn{2}{|c|}{ Equation (12) } & Equation (15) \\
\hline & \multicolumn{2}{|c|}{ parameters $(t$ statistics $)$} & \multicolumn{2}{|c|}{ parameters $(t$ statistics $)$} & parameters ( $t$ statistics $)$ \\
\hline$\overline{\text { Wage (log term) }}$ & 0.10 & $(20.12)$ & 0.11 & $(23.81)$ & $\begin{array}{ll}0.11 \quad(24.14) \\
\end{array}$ \\
\hline Age (years) & 0.00 & $(-31.12)$ & 0.00 & $(-41.94)$ & $(-35.82)$ \\
\hline CPI (log term) & -0.31 & $(-3.57)$ & -0.43 & $(-12.09)$ & $(-12.97)$ \\
\hline Number of household members & -0.03 & $(-0.58)$ & 0.05 & $(13.29)$ & ( 11.49) \\
\hline Share of self-employed & 0.31 & $(2.35)$ & 0.18 & $(7.60)$ & ( 7.55) \\
\hline Share of primary industry & 0.42 & $(2.16)$ & 0.74 & (16.99) & $(16.48)$ \\
\hline Consumption (log term) & & & -0.02 & $(-1.89)$ & \\
\hline Net Expenditures (log term) & & & & & $(0.00)$ \\
\hline Constant & 6.43 & $(14.82)$ & 6.91 & $(41.06)$ & $6.86 \quad(41.02)$ \\
\hline Other control variables & $\begin{array}{l}\text { year, pre } \\
\text { birth cohol }\end{array}$ & $\begin{array}{l}\text { ecture, } \\
\text { dummies }\end{array}$ & year du & imies & year dummies \\
\hline R-squared & 0.7 & & 0. & & 0.72 \\
\hline \multirow[t]{3}{*}{ Labor supply elasticities } & \multicolumn{2}{|c|}{ Frisch elasticity } & \multicolumn{2}{|c|}{ "m-supply elasticity } & \multirow{2}{*}{$\begin{array}{c}\text { Marshalian elasticity } \\
0.11 \quad \text { ( 24.14) } \\
\text { Hicksian elasticity }\end{array}$} \\
\hline & 0.10 & $(20.12)$ & 0.11 & ( 23.81) & \\
\hline & & & & & $0.11 \quad(20.20)$ \\
\hline
\end{tabular}

\section{(2) By Sex}

\begin{tabular}{|c|c|c|c|c|}
\hline & \multicolumn{2}{|c|}{ Males } & \multicolumn{2}{|c|}{ Females } \\
\hline & \multicolumn{2}{|c|}{ parameters $(t$ statistics $)$} & \multicolumn{2}{|c|}{ parameters ( $t$ statistics) } \\
\hline Wage (log term) & 0.14 & $(33.78)$ & 0.13 & $(7.25)$ \\
\hline Age (years) & 0.00 & $(-32.82)$ & 0.00 & $(-17.50)$ \\
\hline CPI (log term) & -0.37 & $(-3.92)$ & -0.38 & $(-3.60)$ \\
\hline Number of household members & 0.00 & $(-0.03)$ & -0.08 & $(-1.36)$ \\
\hline Share of self-employed & 0.35 & $(2.46)$ & 0.29 & $(2.05)$ \\
\hline Share of primary industry & 0.55 & $(2.54)$ & 0.09 & $(0.40)$ \\
\hline Constant & 6.59 & $(13.66)$ & 6.74 & $(13.27)$ \\
\hline Other control variables & \multicolumn{2}{|c|}{$\begin{array}{c}\text { year, prefecture, } \\
\text { birth cohort dummies }\end{array}$} & \multicolumn{2}{|c|}{$\begin{array}{c}\text { year, prefecture, } \\
\text { birth cohort dummies }\end{array}$} \\
\hline R-squared & \multicolumn{2}{|c|}{0.76} & \multicolumn{2}{|c|}{0.85} \\
\hline \multirow[t]{2}{*}{ Labor supply elasticities } & \multicolumn{2}{|c|}{ Frisch elasticity } & \multicolumn{2}{|c|}{ Frisch elasticity } \\
\hline & 0.14 & (33.78) & 0.13 & $(7.25)$ \\
\hline
\end{tabular}


Figure 1 Changes in Frisch Elasticity: Dataset A

\section{(1) Intensive and Extensive Margins Combined}

\section{a. Both sexes}

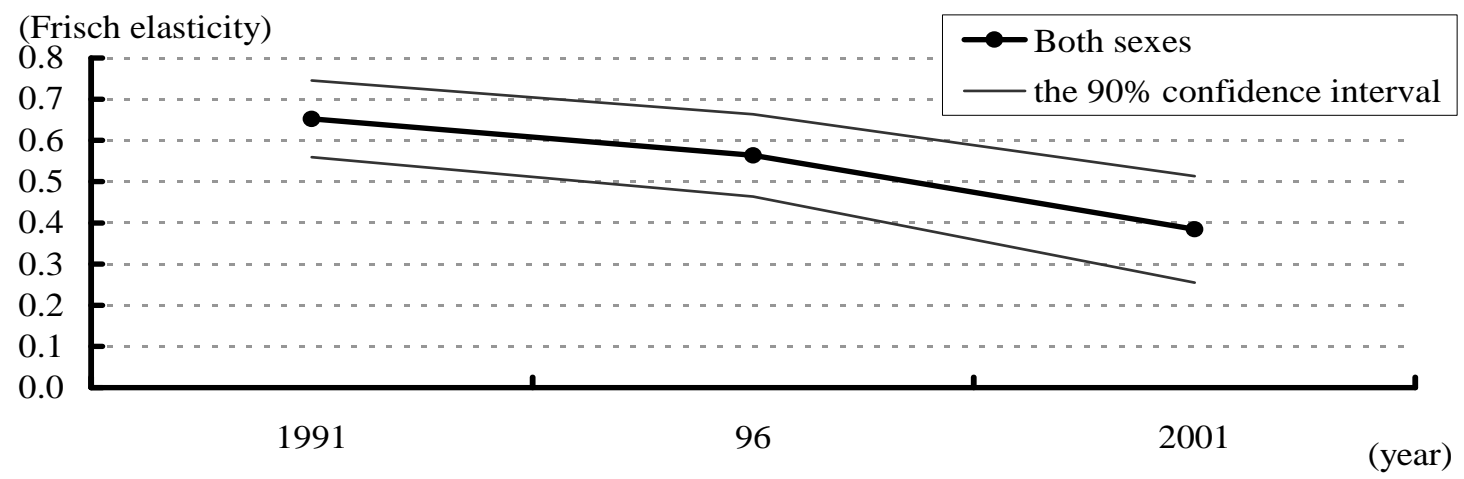

\section{b. Male}

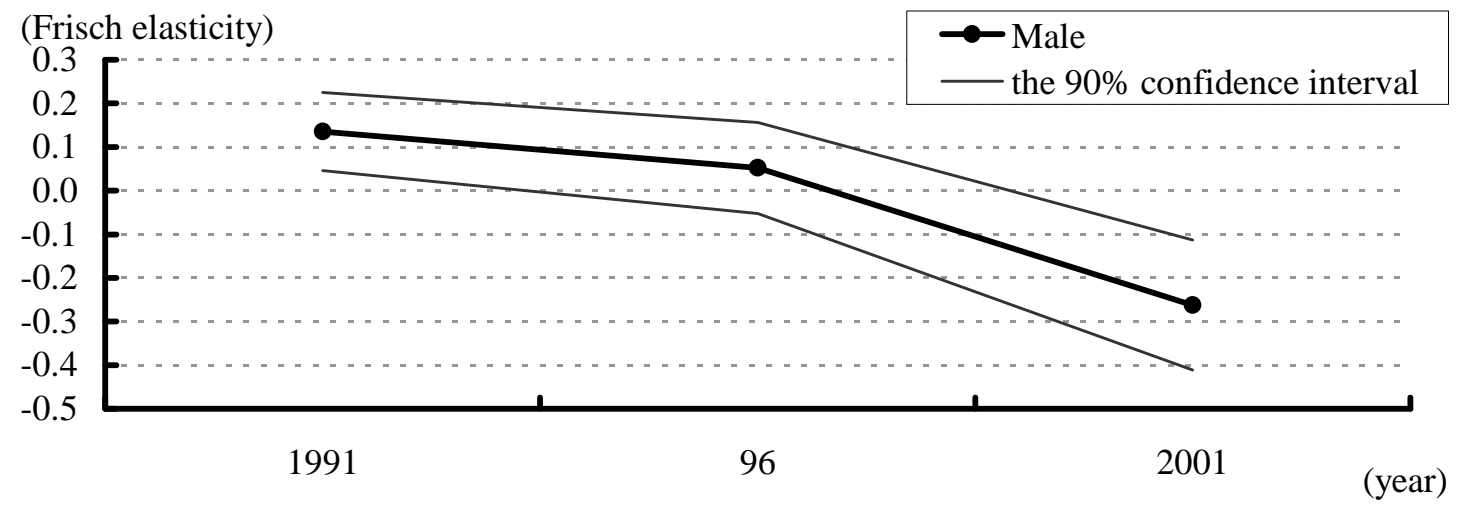

\section{c. Female}

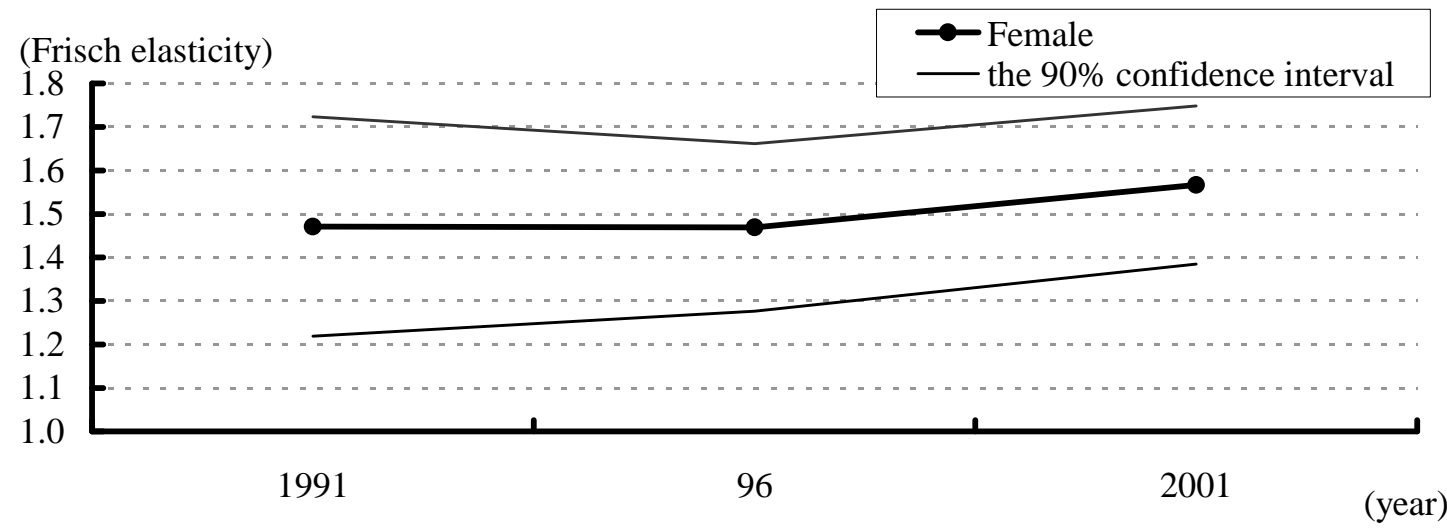


Figure 1 (continued)

\section{(2) Intensive Margin}

\section{a. Both sexes}

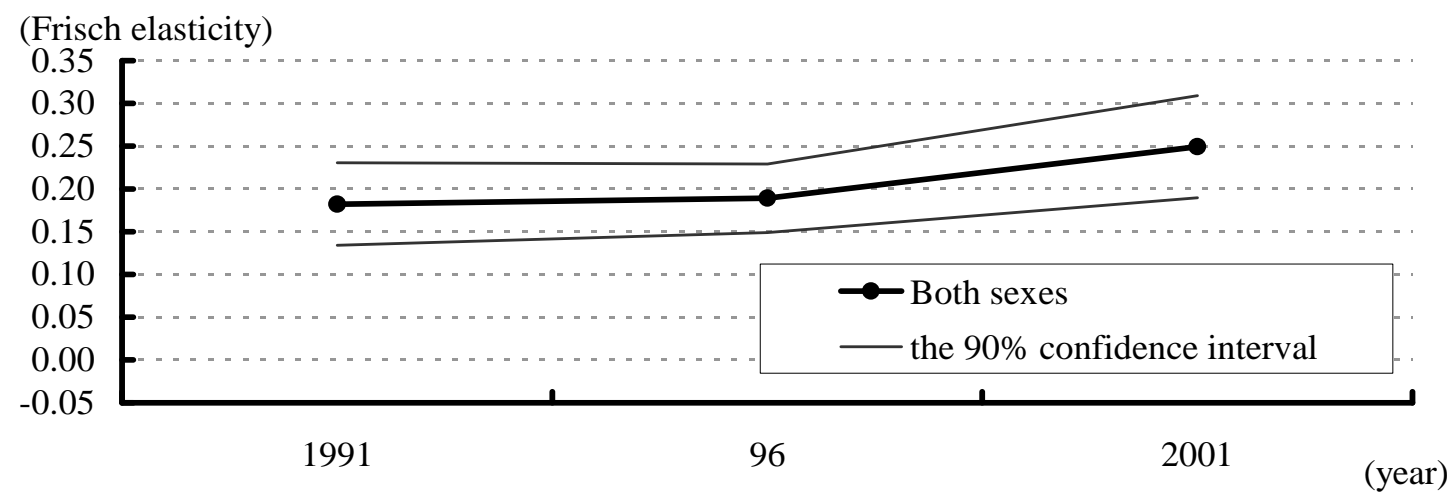

\section{b. Male}

(Frisch elasticity)

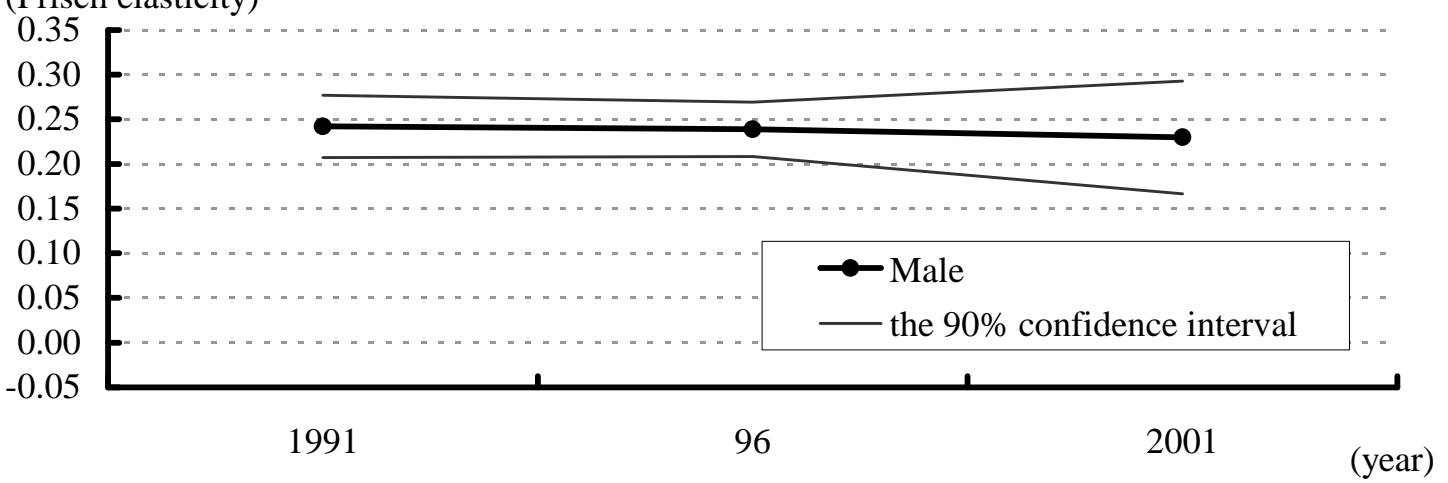

\section{c. Female}

(Frisch elasticity)

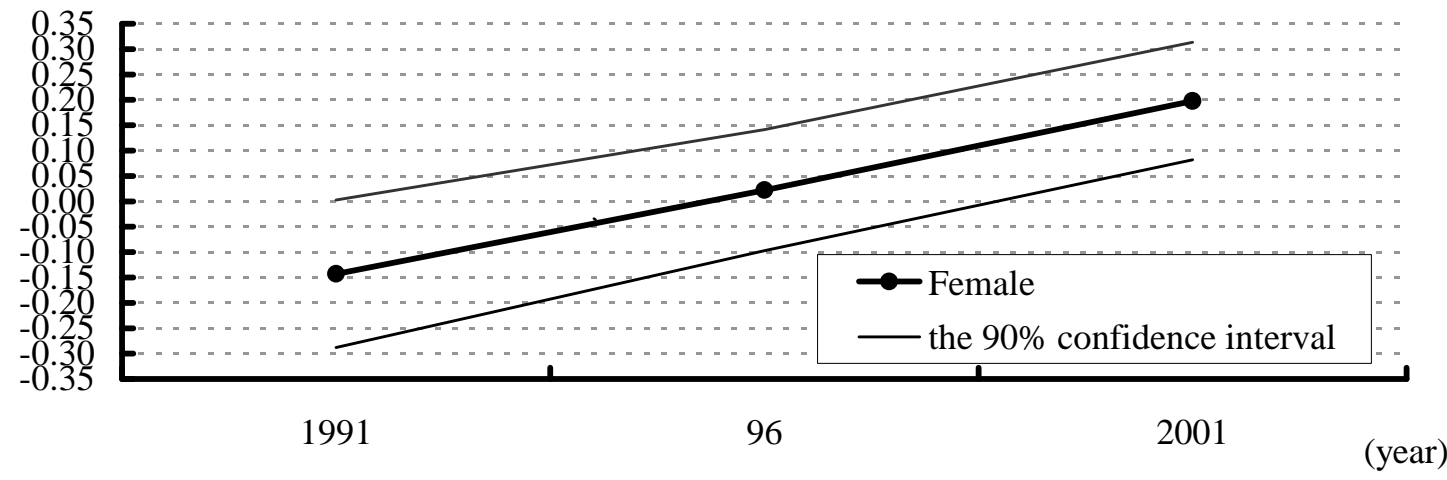


Figure 2 Changes in Frisch Elasticity: Dataset B

\section{(1) Intensive and Extensive Margins Combined}

\section{a. Both sexes}

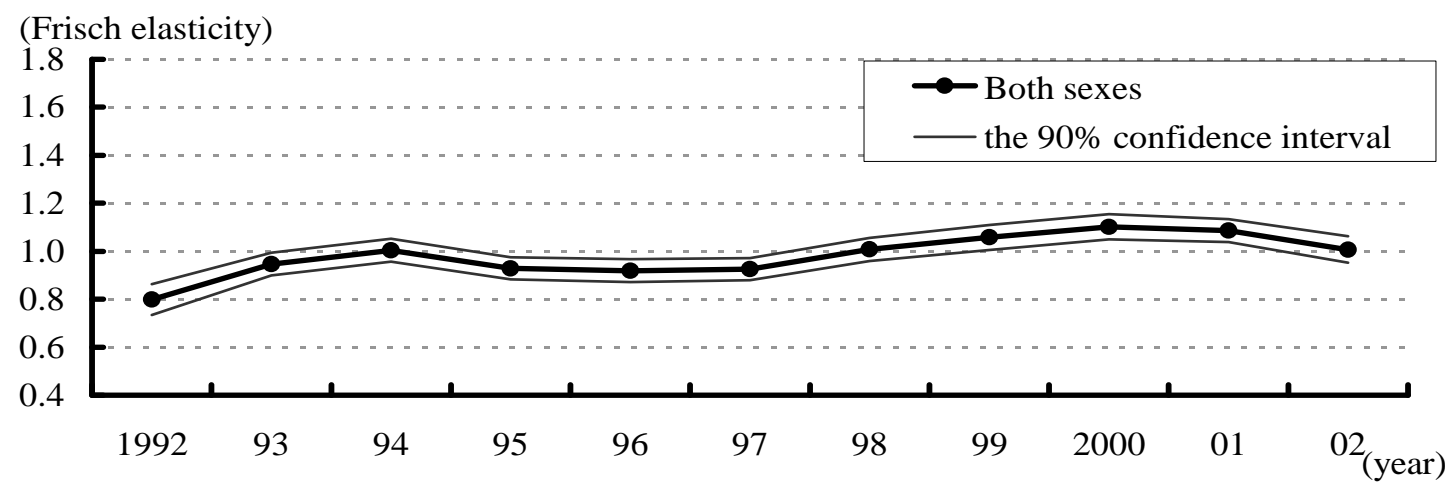

\section{b. Male}

(Frisch elasticity)

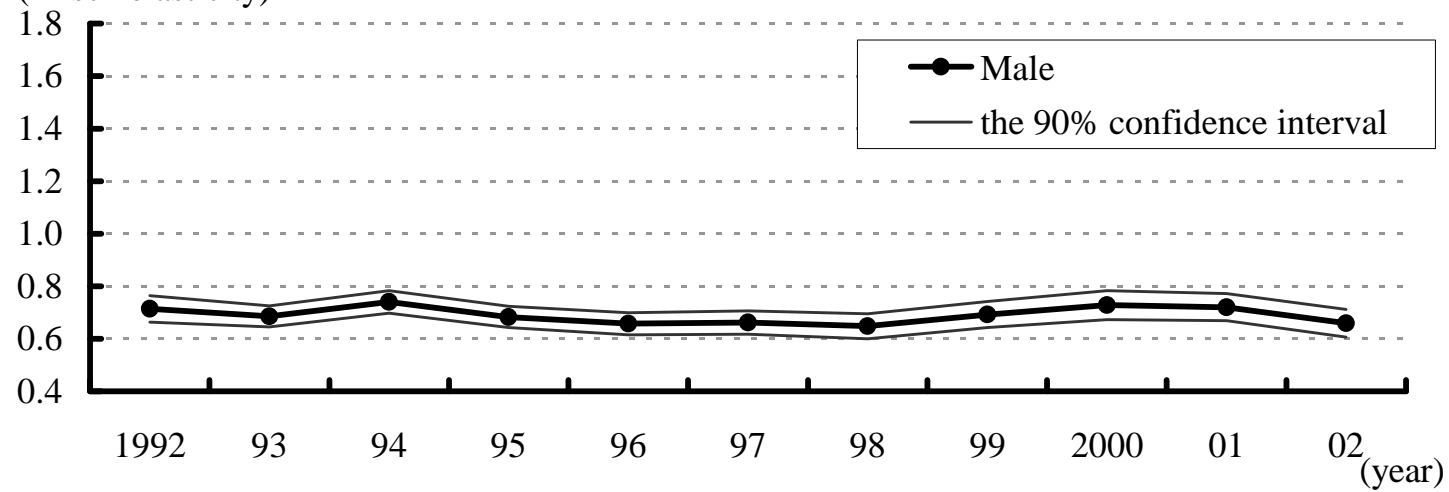

\section{c. Female}

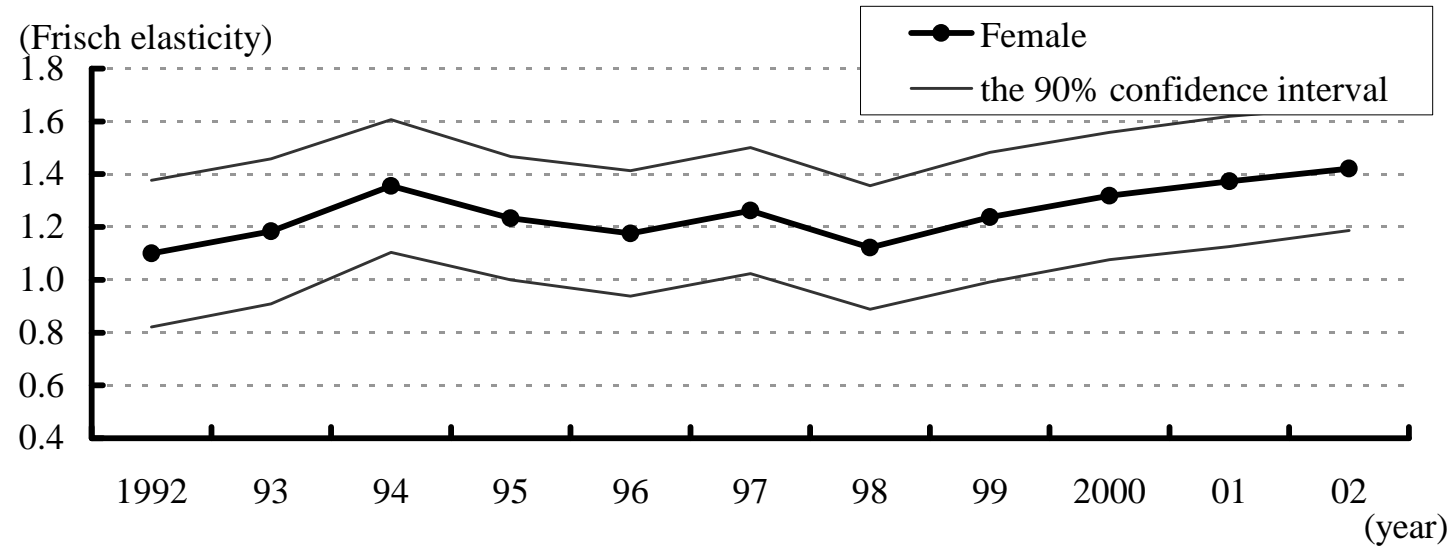


Figure 2 (continued)

\section{(2) Intensive Margin}

\section{a. Both sexes}

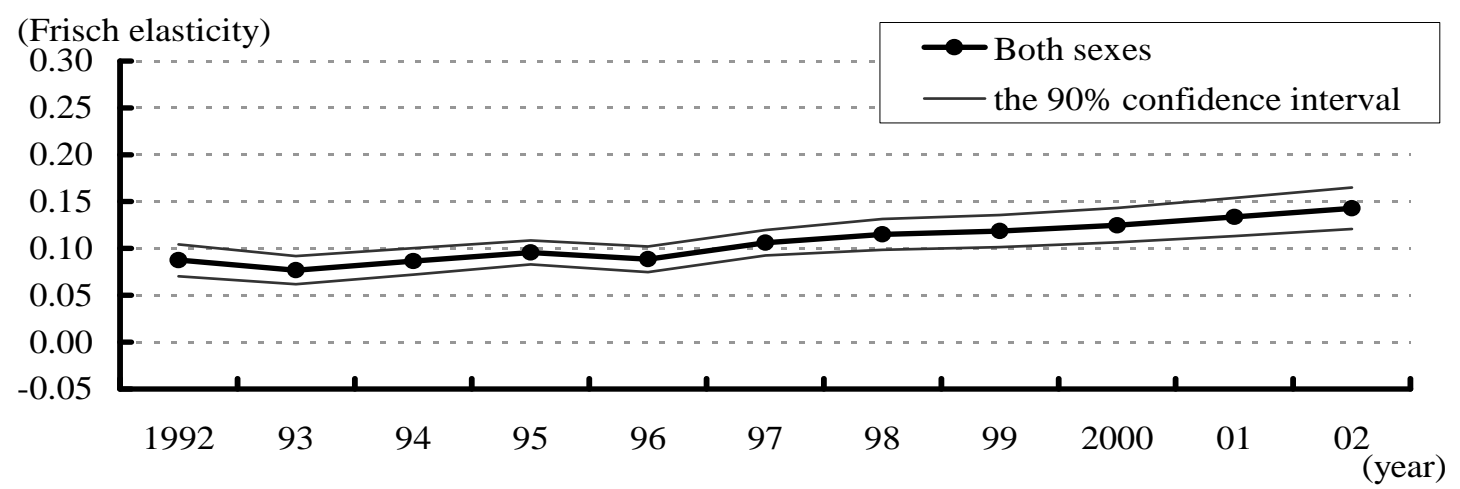

\section{b. Male}

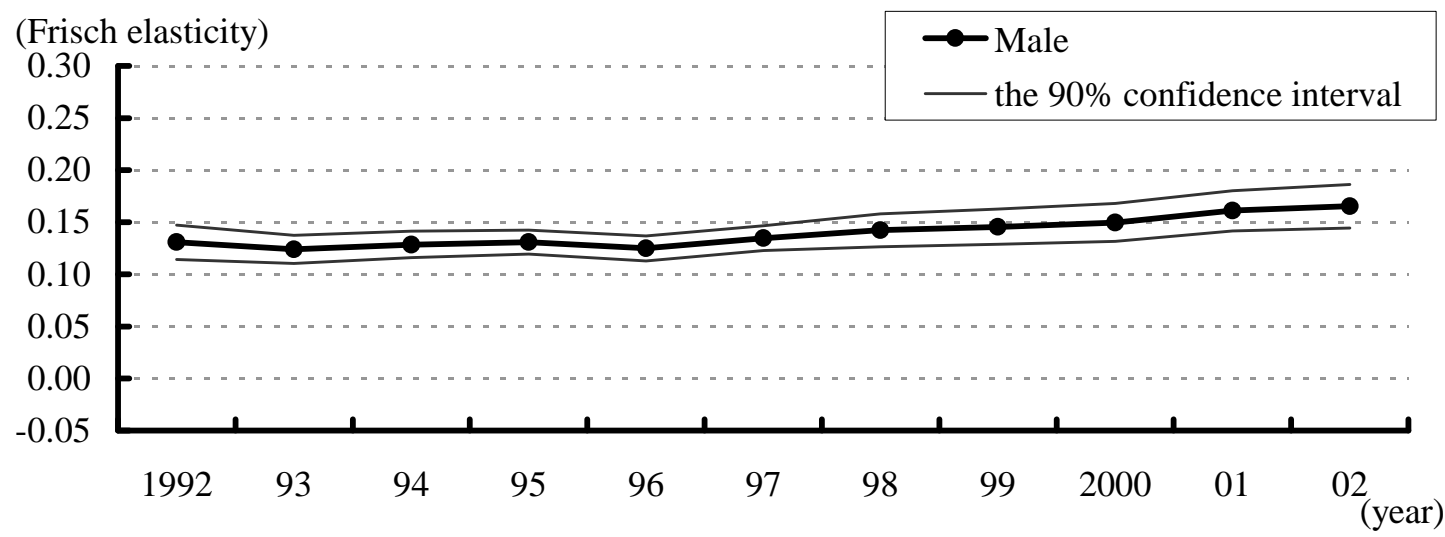

\section{c. Female}

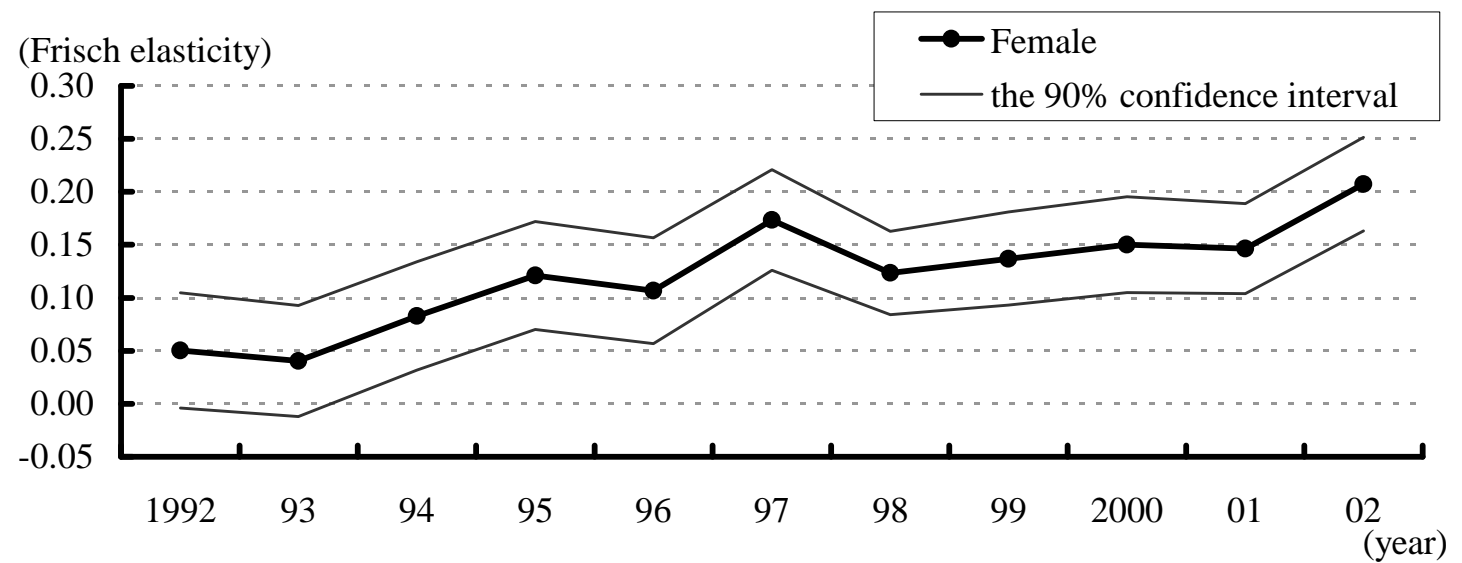

